\title{
Yoğun Bakım Hastalarının Endotrakeal Entübasyonunda Ortaya Çıkan Metabolik ve Hemodinamik Yanıtlara Ketamin ve Etomidatın Etkilerinin Karşılaştırılması
}

\author{
Hemodynamic and Metabolic Responses to Ketamine and Etomidate \\ Sedations During Endotracheal Intubation in Critically ill Patients
}

Özlem Çınar, Arash Pirat, Pınar Zeyneloğlu, Aynur Camkıran, Nilüfer Bayraktar, Coşkun Araz, Gülnaz Arslan

Başkent Üniversitesi Tıp Fakültesi, Anesteziyoloji Anabilim Dalı, Ankara, Türkiye

\section{ÖZET}

Amaç: Bu çalıșmanın amacı yoğun bakım hastalarının endotrakeal entübasyonunda sedasyon amaçlı verilen etomidat ve ketaminin hemodinamik ve metabolik yanıta etkilerini karşılaştırımaktır.

Gereç ve Yöntem: Araştırma ve Etik Kurulları'nın onayı alınarak, prospektif, randomize ve çift kör olarak planlanan çalışmaya yoğun bakım ünitesinde (YBÜ) acil entübasyon intiyacı olan toplam 22 yoğun bakım hastası dahil edildi. Hastalar iki gruba ayırıldı, grup $E(n=12) 0,3 \mathrm{mg} / \mathrm{kg}$ intravenöz etomidat ve grup $\mathrm{K}(\mathrm{n}=10) 2 \mathrm{mg} / \mathrm{kg}$ intravenöz ketamin olacak şekilde endotrakeal entübasyon sırasında sedatize edildi.

Bulgular: Her iki grupta da yer alan hastaların demografik özellikleri ve YBU'ye kabul nedenleri benzerdi $(p>0,05)$. Ortalama kalp hızı ve arteriyel kan basıncı değerleri entübasyon öncesi ve sonrasında farkllık göstermedi $(p>0,05)$. Grupların ortalama serum kortisol ve $11 \beta$ deoksikortizol konsantarasyonları entübasyon öncesinde ve 5 dak sonra benzerdi $(p>0,05)$. Entübasyon koşulları, mortalite, yoğun bakımda kalıs süresi ve mekanik ventilasyon süresi arasında gruplar arasında fark yoktu $(p>0,05)$. Entübasyondan sonraki 9 gün boyunca bakılan sequential organ failure assesment (SOFA) skorları iki grupta da benzer bulundu $(p>0,05)$

Sonuç: Çalışmamızın sonuçları yoğun bakım hastalarının entübasyonunda hemodinamik ve metabolik stabilitenin korunması, entübasyon koşulları ve ortalama SOFA skorları açısından ketaminin etomidata alternatif olabileceğini göstermektedir. (Türk Yoğun Bakım Derneği Dergisi 2011; 9: 77-84)

Anahtar Kelimeler: Endotrakeal entübasyon, ketamin, etomidat, metabolik yanıt, hemodinamik yanıt, yoğun bakım

\section{SUMMARY}

Yazışma Adresi/Address for Correspondence: Dr. Aynur Camkıran, Başkent Üniversitesi Tıp Fakültesi, Anesteziyoloji ve Biyokimya Anabilim Dalı, Ankara, Türkiye Tel.: +90 31221268 68/1172-4 Faks: +90 3122121583 E-posta: acamkiran@gmail.com Geliş Tarihi/Received: 02.06.2011 Kabul Tarihi/Accepted: 27.08.2011

Türk Yoğun Bakım Derneği Dergisi, Galenos Yayınevi tarafından basıımıştır. / Journal of the Turkish Society of Intensive Care, published by Galenos Publishing. ISNN: $1300-5804$ 


\section{Giriş}

Yoğun bakım hastalarında havayolunun kontrolü ve mekanik ventilasyon için sıklıkla endotrakeal entübasyona intiyaç duyulmaktadır. Endotrakeal entübasyon, bilinci açık olan hastalarda rahatsız edici bir işlem olduğundan bu işlemin yapılabilmesi için genellikle sedasyon gerekmektedir. Ancak, hemodinamik sistem başta olmak üzere çoğu zaman birçok organ sisteminde önemli sorunları olan yoğun bakım hastalarında uygun sedatif ajanın seçimi konusunda görüş birliği yoktur. Etomidat, kısa etkili olması, endotrakeal entübasyona izin veren gevşemeyi sağlaması ve daha önemlisi bunları yaparken sağladığı hemodinamik stabilite nedeniyle en çok tercih edilen ajanlardandır (1-2). Ancak etomidatın sürekli infüzyonu veya tekrarlayan dozlarının adrenal supresyon yaparak yoğun bakım hastalarında mortaliteyi artırabileceği bildirilmiştir (3). Ancak Annane ve ark. (4) entübasyonda tek doz etomidat kullanılan septik şoklu yoğun bakım hastalarında da mortalite ve yoğun bakımda kalış sürelerinin artabileceğini bildirmişlerdir. Vinclair ve ark. (5) ise tek doz etomidat verilen septik şoklu hastalarda adrenal mitokondrial hidroksilaz aktivitesinin inhibisyonu sonucu steroid sentezinin geri dönüşümlü olarak azaldığını göstermişlerdir. Etomidatın bu olumsuz etkileri yoğun bakım hastalarının endotrakeal entübasyonu sırasında sedasyon için farklı ajanların kullanımını gündeme getirmiştir.

Ketamin, adrenal aksı inhibe etmeyen ve kardiyorespiratuvar depresyon yapmayan bir ilaç olması nedeni ile yoğun bakım hastalarının entübasyonu sırasında sedasyon için etomidat yerine tercih edilebilecek bir ajandır. KETASED çalışması kritik hastaların entübasyonunda ketaminin etomidat gibi güvenli ve önemli bir alternatif olduğunu göstermiştir (6). Ancak bu çalışmada bu iki sedatif ajanın yoğun bakım hastalarının entübasyonunda hemodinamik ve metabolik yanıtları nasıl etkilediği incelenmemiştir.

Yoğun bakım hastalarının endotrakeal entübasyonunda sedasyon amaçlı verilen etomidat ve ketaminin karşılaştırıldığı bu çalışmada birincil amaç bu ilaçların hemodinamik etkilerinin incelenmesi, ikincil amaçlar ise entübasyona metabolik yanıt, entübasyon koşulları ve yoğun bakım morbiditelerinin değerlendirilmesi idi.

\section{Gereç ve Yöntem}

Başkent Üniversitesi Araştırma ve Etik Kurulları̀nın onayı (KA09/27 01/04/2009) alınarak toplam 22 yoğun bakım hastası çalışmaya dahil edildi. Yoğun bakımda acil entübasyon ihtiyacı olan hastalar entübe edildikten sonra yakınlarına bilgi verildi. Daha sonraki işlemler için izin alınan ve aydınlatımış onay formu imzalanan hastalar çalışmaya dahil edildi. Glasgow koma skoru (GKS) 8'in altında, bilinç durum değişikliği olan; $\mathrm{PaCO}_{2} \geq 60 \mathrm{mmHg}$ veya $\mathrm{PaO}_{2} / \mathrm{FiO}_{2}$ oranı 300'ün altında olan takipneik, hipoksik veya hiperkapneik hastaların acil entübasyon ihtiyacı olduğu kabul edilerek işlem gerçekleştirildi. Entübasyon ihtiyacı yoğun bakım sorumlusu anestezi doktoru tarafından belirlendi ve arrest durumundaki hastalar çalışmaya alınmadı. Çalışma prospektif, randomize, kontrollü, çift-kör düzende yapıldı. Tüm entübasyonlar aynı kişi tarafından gerçekleştirildi (Ö.Ç.). Hastalar entübasyon sırasında sedasyon için etomidat verilen grup $\mathrm{E}$ ve ketamin verilen grup $\mathrm{K}$ olmak üzere iki gruba ayrıldı. Önceden kortikosteroid kullanan, adrenal yetmezlik öyküsü olan, imidazol grubu antifungal ilaç kullanan, serum albumin $<2,5 \mathrm{~g} / \mathrm{dL}$ olan ve psikotik bozukluk hikayesi olan hastalar çalışma dışı bırakıldı. Randomizasyon web tabanlı Random Number Generator programı kullanılarak yapıldı.

Entübasyonda kullanılacak ilaçlar onarlı gruplar halinde beşi etomidat beşi ketamin-midazolam kombinasyonu olmak üzere önceden hazırlanıp çalışmaya dahil olmayan bir klinisyen tarafından web tabanlı Random Number Generator programı kullanılarak randomize numaralandırıldı. Ilaçlar 20 ml'lik enjektörlere ml'de 10 mg ketamin ve 0,15 mg midazolam veya $1,5 \mathrm{mg}$ etomidat olacak şekilde hazırlandı. Hastalara ilaç uygulanırken 0,3 mg/kg intravenöz etomidat (Hypnomidate ${ }^{\circledR}$ ) veya $2 \mathrm{mg} / \mathrm{kg}$ intravenöz ketamin 0,03 $\mathrm{mg} / \mathrm{kg}$ midazolam kombinasyonu olacak şekilde doz ayarlandı. Numaralandırılmış ilaçlar buzdolabında saklanarak acil entübasyon sırasında ilacın içeriğini bilmeyen yoğun bakım sorumlusu anestezist tarafından rastgele seçilerek kullanıldı. Ilacın numarası kaydedildi.

Hastaların entübasyon sırasında vazopressör ihtiyacı olup olmadığı, entübasyon sırasında gelişen bradi- ve taşiaritmiler, ek sedasyon ihtiyacı, entübasyon deneme sayısı kaydedildi. Entübasyon için uygun sedasyon sağlanamayan ek ilaca ihtiyaç duyulan durumlarda uygulanan ilaç yarı dozda tekrarlandı.

Entübasyon koşullarının uygunluğu 6 parametreden oluşan laringoskopi derecelendirme skalası ile değerlendirildi. Bu skala ile çene gevşekliği, hasta direnci, vokal kordların pozisyonu ve hareketi, öksürük ve ekstremite hareketleri değerlendirilerek entübasyon iyi, orta ya da kötü olarak derecelendirildi.

Entübasyona hemodinamik yanıtın değerlendirilmesi için hastaların kalp hızları ile radiyal arterden invaziv olarak takip edilen sistolik, diyastolik ve ortalama kan basınçları entübasyon öncesinde (TO) ve entübasyondan sonra ilk 5 dakikada 1 dakikalık aralıklarla (T1, T2, T3, T4, T5) daha sonra 55 dakika süreyle 5 dakikalık aralıklarla (T10, T15, T20 vs.) kaydedildi.

Tüm hastaların demografik bilgileri (yaş, cinsiyet, kilo, boy) kaydedildi. Yoğun bakıma kabulleri sırasında mevcut sistemik hastalıkları (hipertansiyon, diabetes mellitus, koroner arter hastalığı, kronik obstruktif akciğer hastalığı, böbrek yetmezliği vs.), yoğun bakıma kabul ediliş nedenleri 
(sepsis, solunum yetmezliği, hepatik ensefalopati, intrakraniyal kanama vs.) ve yoğun bakımda gelişen sorunlar (akut böbrek hasarı, akut respiratuvar distres sendromu, bilinç değişikliği, enfeksiyon vs.) kaydedildi.

Tüm hastaların yoğun bakıma kabulleri sırasında mevcut sağlık durumlarını ve hastalığın ciddiyetini değerlendirmek amaciyla acute physiolgy and chronic health evaluation-II (APACHE II) skorları hesaplandı.

Hastalar yoğun bakımda kaldıkları süre içerisinde organ sistem fonksiyonları altı major organ sisteminin değerlendirildiği günlük sequential organ failure assesment (SOFA) skorları ile takip edildi. Bu skorlama sistemi ile hastaların kardiyovasküler, respiratuvar, renal, hepatik, santral sinir ve koagülasyon sistemleri günlük değerlendirildi. $\mathrm{Bu}$ amaçla hastaların günlük hemodinamik parametreleri, billirubin, kreatinin, trombosit değerleri, GKS, $\mathrm{PaO}_{2} / \mathrm{FiO}_{2}$ oranları kaydedildi. Her organ sistemi için 0-4 arası puan verilen bu skorlama sistemi ile elde edilen 0-24 arası skor ile organ disfonksiyonu varlığı ve ciddiyeti belirlendi.

Çalışmaya alınan hastalardan ikisi yoğun bakım takiplerinde steroid aldıkları için çalışma dışı bırakıldı. Hastaların takipleri sırasında vazopressör intiyaçları, akut gelişen sorunlar, yoğun bakımda ve ventilatörde kalış süreleri kaydedildi.

Entübasyona stres yanıtın karşılaştırılması için başlangıçta ve entübasyondan sonra 5. dakikada serum kortizol ve 11ßdeoksikortizol seviyelerinin ölçümü amacıyla radiyal arterden kan örnekleri alındı. Kan örnekleri 3000 devirle 5 dakika santrifüj edildikten sonra ayrlan plazmalar analiz edilinceye kadar $-20^{\circ} \mathrm{C}$ 'de saklandı. Ayrılan plazmalardan kortizol ölçümü için solid faz, kompetatif Immulite 2000 cortizol chemiluminescent enzyme immunoassay yöntemi kullanıldı. $11 \beta$-deoksikortizol ölçümü ise ayrlan plazmalardan RIA (Radioimmunoassay) yöntemi ile yapıldı. Bu yöntemde minimum saptanabilir konsantrasyon $0,11 \mathrm{ng} / \mathrm{ml}$ idi.

\section{İstatistiksel Analiz}

Verilerin analizi SPSS 14,0 (Statistical Package for Social Sciences, SPSS Inc., Chicago, IL, United States) yazılımı kullanılarak gerçekleştirildi. Sürekli veriler ortalama \pm standart deviasyon ve sürekli olmayan veriler sayı (\%) olarak belirtildi. Şekil 1, 2, 3 ve 4'te grafiklerin daha anlaşlır olması için çubuklar standart sapma yerine standart hatayı temsil etmektedir. Grupların karşılaştııımasında homojen dağılım gösteren sürekli veriler için student-t testi, homojen dağlım göstermeyen veriler için Mann-Whitney $U$ testi kullanıldı. Sürekli olmayan (kategorik) verilerin karşılaştıııması ise kikare testi ile yapıldı. Birden fazla değerin kaydedildiği kan basıncı ve kalp hızı gibi verilerin grup içi ve gruplar arası karşılaştırmalarında ise tekrarlayan ölçümler yöntemi kullanıldı. Anlamlı farklıık saptanan parametrelerin post hoc analizi ise Bonferroni düzeltilmesi ile yapıldı. $p<0,05$ değeri anlamlı olarak kabul edildi.

\section{Bulgular}

Gruplar arasında demografik özellikler ve sistemik hastalıklar açısından anlamlı farklılık saptanmadı (tüm karşılaştırmalar için $p>0,05$, Tablo 1). Ortalama APACHE ॥ skoru açısından karşılaştııılığında gruplar arasında anlamlı farklılık yoktu ( $p>0,05$, Tablo 2). Hastaların yoğun bakıma kabul edilme nedenleri iki grup arasında benzerdi (tüm karşılaştırmalar için $p>0,05)$. Hastaların önemli bir bölümünde yoğun bakıma geliş nedeni sepsis ve solunum yetmezliği iken, akut böbrek hasarı, intrakranial kanama, postoperatif atelektazi ve hepatik ensefalopati rastlanan diğer nedenlerden idi (Tablo 2). Her iki grupta entübasyon nedenleri benzer bulundu (tüm karşılaştırmalar için $p>0,05$ ). Koma, solunum yetmezliği ve şok dışında 1 hasta kalp yetmezliği, 1 hasta ise postoperatif atelektazi nedeniyle entübe edildi (Tablo 2).

Her iki grupta entübasyon sırasında vazopressör intiyacı olan ve aritmi gelişen hasta sayısı benzerdi (tüm karşılaştırmalar için $p>0,05)$. Her iki gruptan birer hastada entübasyon sonrası erken dönemde kardiyak arrest gelişti. Işlem öncesi vazopressör almakta olan ve durumları hızla bozulan bu hastalardan biri resusitasyon sonrası 5 . dakikada normale döndü. Diğer hasta ise entübasyon sonrası 10. dakikada arrest oldu, resusitasyona yanıt alınamadı. Entübasyon için ek sedatif ilaç gereksinimine her iki grupta birer hastada rastlandı. Laringoskopi derecelendirme skalası ile yapılan değerlendirmede iki grup arasında entübasyon

Tablo 1. Hastaların demografik özellikleri [ortalama \pm SD (ortalamalar için \%95 güvenlik aralığı) veya sayı (\%)]

\begin{tabular}{lccc} 
& $\begin{array}{c}\text { Grup E } \\
(\mathbf{n = 1 2 )}\end{array}$ & $\begin{array}{c}\text { Grup K } \\
(\mathbf{n = 1 0 )}\end{array}$ & p değeri \\
\hline Demografik özellikler & & & \\
Yaş (yıl) & $63,8 \pm 20,3$ & $72,5 \pm 7,8$ & 0,355 \\
& $(50,9-76,7)$ & $(66,9-78,0)$ & \\
Kadın & $7(\% 58)$ & $4(\% 40)$ & 0,670 \\
Ağırlık (kg) & $68,6 \pm 8,4$ & $67,2 \pm 10,5$ & 0,790 \\
& $(63,2-73,9)$ & $(59,6-79,7)$ & \\
Boy (cm) & $165,0 \pm 8,6$ & $167,2 \pm 6,6$ & 0,565 \\
& $(159,5-170,4)$ & $(162,4-171,9)$ & \\
Sistemik hastalıklar & & & \\
Hipertansiyon & $10(\% 83)$ & $7(\% 70)$ & 0,624 \\
Koroner arter hastalığı & $3(\% 25)$ & $3(\% 30)$ & 1,000 \\
KOAH & $0(\% 0)$ & $3(\% 30)$ & 0,078 \\
Konjestif kalp yetmezliği & $1(\% 8)$ & $3(\% 30)$ & 0,293 \\
KBY & $2(\% 17)$ & $0(\% 0)$ & 0,481 \\
Diabetes mellitus & $3(\% 25)$ & $3(\% 30)$ & 1,000 \\
Serebrovasküler hastalık & $4(\% 33)$ & $2(\% 20)$ & 0,646 \\
\hline KOAH (kronik obstruktif akciğer hastalı̆ı̆) & & \\
KBY (kronik böbrek yetmezliği) & & & \\
\hline
\end{tabular}


Tablo 2. Gruplara göre hastaların APACHE II skorları, yoğun

bakıma kabul edilme nedenleri ve entübasyon endikasyonları [grup içi hasta sayısı $\mathbf{n}(\%)$ ]

\begin{tabular}{lccc} 
& $\begin{array}{c}\text { Grup E } \\
(\mathbf{n = 1 2 )}\end{array}$ & $\begin{array}{c}\text { Grup K } \\
(\mathbf{n = 1 0 )}\end{array}$ & p değeri \\
\hline APACHE II & $28,7 \pm 5,4$ & $32,1 \pm 7$ & 0,144 \\
$\begin{array}{l}\text { Yoğun bakım endikasyonları } \\
\text { Çoklu organ yetmezliği }\end{array}$ & $5(\% 47)$ & $4(\% 40)$ & 0,639 \\
$\quad \begin{array}{l}\text { Solunum yetmezliği } \\
\quad \text { Bilinç durum değişikliği }\end{array}$ & $5(\% 47)$ & $4(\% 40)$ & 0,639 \\
$\begin{array}{l}\text { Entübasyon endikasyonları } \\
\quad \text { Koma }\end{array}$ & $2(\% 17)$ & $2(\% 20)$ & 0,632 \\
$\quad$ Solunum yetmezliği & $10(\% 83)$ & $7(\% 30)$ & 0,624 \\
$\quad$ Şok & $1(\% 8)$ & $1(\% 10)$ & 0,624 \\
\hline
\end{tabular}

APACHE II, acute physiology and chronic health evaluation

Tablo 3. Gruplara göre entübasyon sırasında ortaya çıkan sorunlar ve entübasyon koşulları [hasta sayısı (\%)]

\begin{tabular}{lccc} 
& $\begin{array}{c}\text { Grup E } \\
(\mathbf{n = 1 2 )}\end{array}$ & $\begin{array}{c}\text { Grup K } \\
(\mathbf{n}=\mathbf{1 0})\end{array}$ & p değeri \\
\hline Vazopressör kullanımı & $2(\% 17)$ & $2(\% 20)$ & 1,000 \\
Ek sedatif kullanımı & $1(\% 8)$ & $1(\% 10)$ & 1,000 \\
Aritmi & $4(\% 33)$ & $1(\% 10)$ & 0,323 \\
$\begin{array}{l}\text { Entübasyon koşulları } \\
\quad \text { İyi }\end{array}$ & $7(\% 58)$ & $6(\% 60)$ & \\
$\quad$ Orta & $3(\% 25)$ & $3(\% 30)$ & 0,891 \\
$\quad$ Kötü & $2(\% 17)$ & $1(\% 10)$ & \\
& & & \\
\end{tabular}

Tablo 4. Gruplara göre yoğun bakımda gelişen sorunlar ve hasta sonuçları [grup içi hasta sayısı n (\%)]

\begin{tabular}{lccc} 
& $\begin{array}{c}\text { Grup E } \\
(\mathbf{n = 1 2})\end{array}$ & $\begin{array}{c}\text { Grup K } \\
(\mathbf{n = 1 0 )}\end{array}$ & p değeri \\
\hline $\begin{array}{l}\text { Gelişen sorunlar } \\
\text { Akut böbrek hasarı }\end{array}$ & $3(\% 25)$ & $3(\% 30)$ & 1,000 \\
Enfeksiyon & $6(\% 50)$ & $2(\% 20)$ & 0,204 \\
Bilinç durumu değişikliği & $2(\% 16)$ & $5(\% 50)$ & 0,172 \\
ARDS & $10(\% 83)$ & $2(\% 20)$ & 0,008 \\
Diğer & $9(\% 75)$ & $8(\% 80)$ & 0,575 \\
Hasta sonuçları & & & \\
Ölüm & $5(\% 42)$ & $8(\% 80)$ & 0,099 \\
Ventilatörde kalış süresi (gün) & $7,2 \pm 11,3$ & $3,2 \pm 2,4$ & 0,482 \\
Yoğun bakımda kalış süresi (gün) & $12,3 \pm 22$ & $4,3 \pm 27$ & 0,368 \\
\hline ARDS, akut respiratuvar distres sendromu & & & \\
\hline
\end{tabular}

koşulları açısından istatistiksel olarak anlamlı fark bulunmadı ( $p>0,05$, Tablo 3).

Entübasyona hemodinamik yanıtı değerlendirmek amacıyla entübasyondan hemen önce (0. dakika) ve entübasyon sonrası ilk 5 dakika birer dakika arayla, takibinde 55 dakika boyunca beş dakikalık aralıklarla kaydedilen sistolik, diyastolik, ortalama arter basınçları ve kalp hızları bakımından gruplar arasında veya grup içi istatistiksel olarak anlamlı fark bulunmadı (Şekil 1,2,3,4).

Hastaların yoğun bakım takipleri sırasında gelişen sorunlar her iki grupta da benzerdi (tüm karşılaştırmalar için $p>0,05)$. Ancak etomidat grubunda akut respiratuvar distres sendromu (ARDS) gelişme sıklığı ketamin grubundan daha yüksek bulundu ( $p=0,008)$. Etomidat grubunda 10 (\%83) hastada ARDS gelişirken ketamin grubunda bu sayı 2 (\%20) idi. Her iki grupta ventilatörde ve yoğun bakımda kalış süreleri bakımından istatistiksel olarak anlamlı fark bulunmadı $(p>0,05)$. Iki grup arasında mortalite açısından da anlamlı fark bulunmadı ( $p>0,05)$ (Tablo 4). Hastaların yoğun bakım takipleri sırasında 9 gün boyunca günlük hesaplanan SOFA skorları her iki grupta benzer bulundu (Şekil 5).

Hastaların entübasyondan hemen önce (T0) ve entübasyondan sonra 5. dakikada (T5) alınan kan örneklerinden yapılan ölçümlerde iki grup arasında kortizol ve $11 \beta$-deoksikortizol değerleri açısından istatistiksel olarak anlamlı fark bulunmadı (Şekil 6A ve B).

\section{Tartışma}

Yoğun bakım hastalarının entübasyonunda sedasyon amaçlı ketamin ile etomidatı karşılaştırdığımız çalışmamızda elde ettiğimiz veriler ketaminin etomidata alternatif olabileceğini göstermiştir. Yoğun bakımda acil entübasyon gereksinimi olan 22 hastada yaptığımız bu çalışmada hemodinamik stabilitenin korunması ve entübasyona hemodinamik ve metabolik yanıt açısından ketaminin etomidat

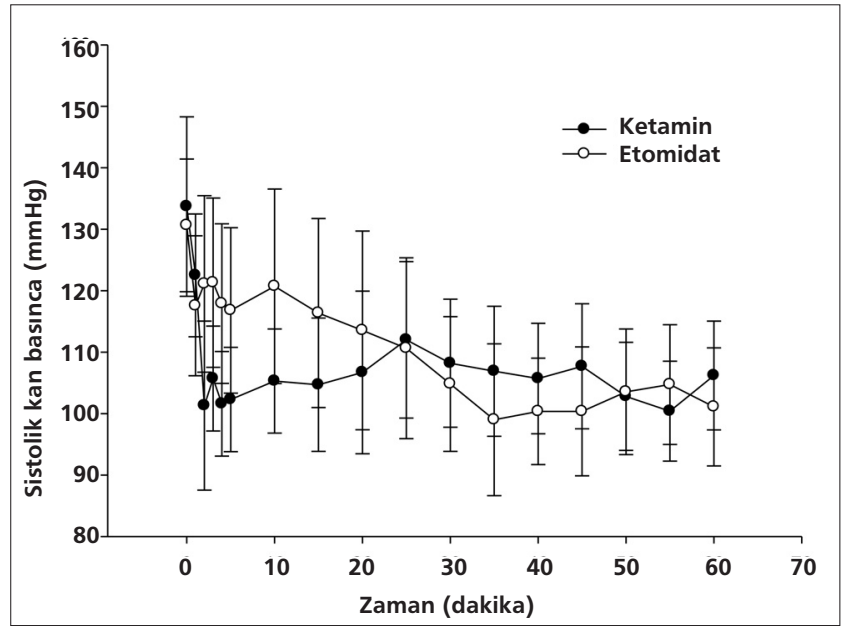

Şekil 1. Hastaların 0. dakika ve takibinde 60 dakikalık sistolik arter basınçları (ortalama \pm standart hata) 


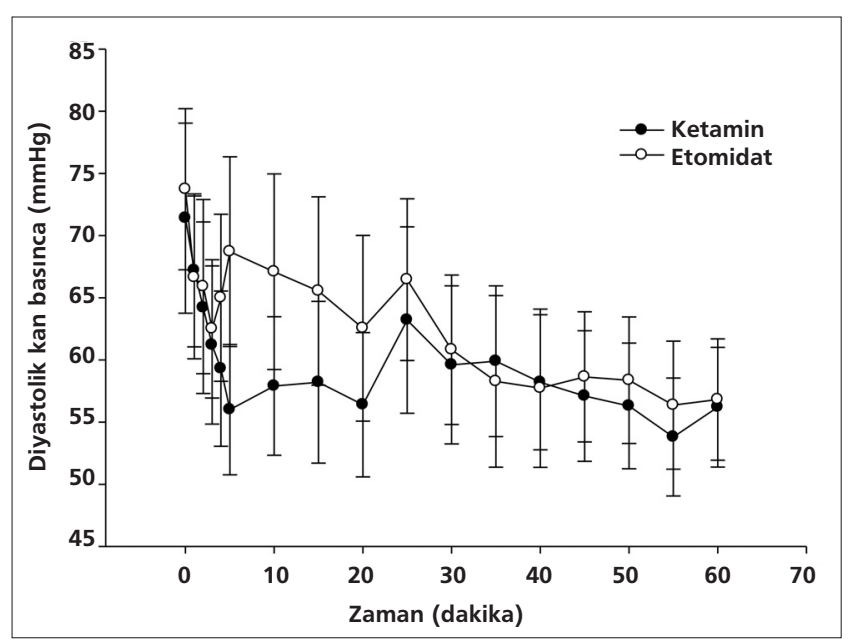

Şekil 2. Hastaların 0. dakika ve takibinde 60 dakikalık diyastolik arter basınçları (ortalama \pm standart hata)

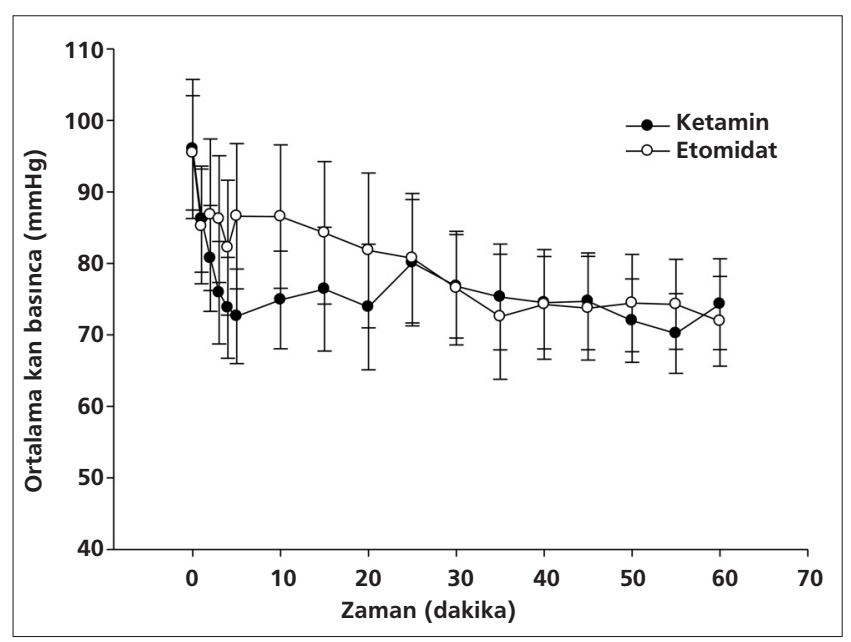

Şekil 3. Hastaların 0. dakika ve takibinde 60 dakikalık ortalama arter basınçları (ortalama \pm standart hata)

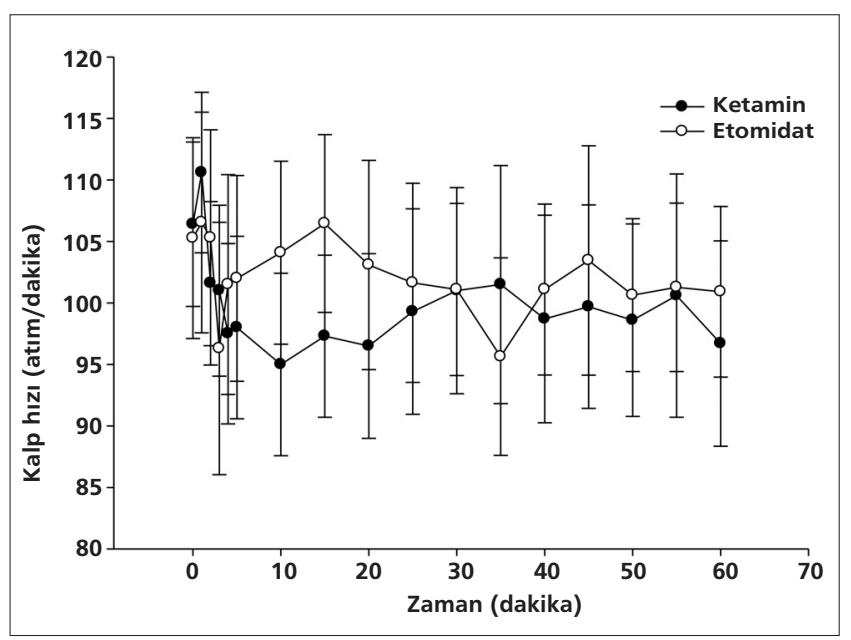

Şekil 4. Hastaların 0. dakika ve takipte 60 dakikalık kalp hızları (ortalama \pm standart hata) için iyi bir alternatif olabileceğini saptadık. Ayrıca, mortalite, morbidite, entübasyon koşulları ve entübasyona hemodinamik yanıt açısından etomidat verilen grup ile ketamin verilen grup arasında istatistiksel olarak anlamlı fark saptanmadı.

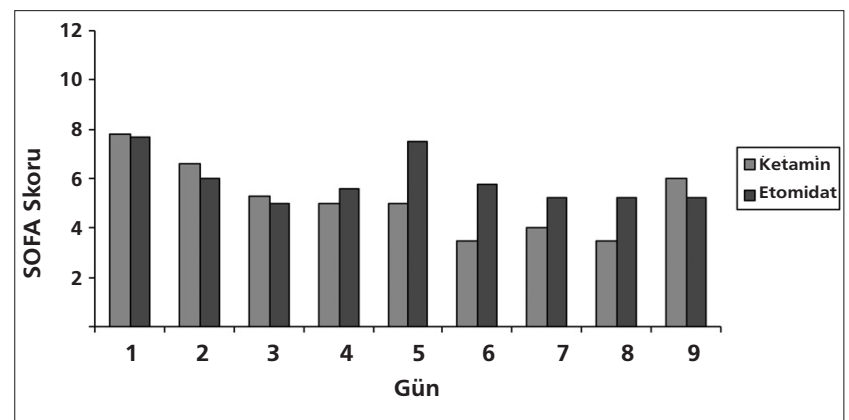

Şekil 5. Grupların entübasyon sonrası 9 günlük SOFA skorları (SOFA, sequential organ failure assessment)
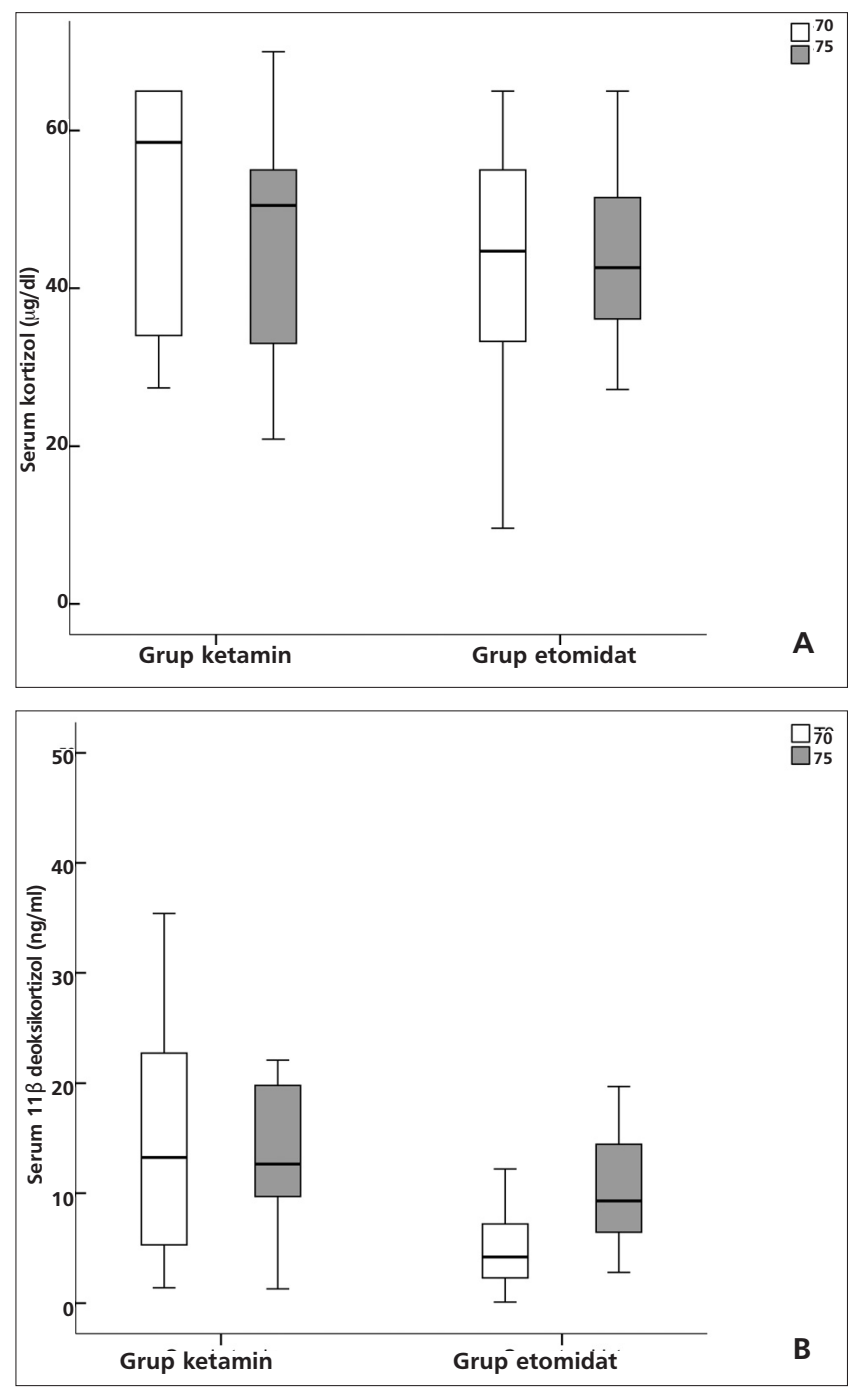

Şekil 6. Grupların serum kortizol (A) ve 11ß-deoksikortizol (B) düzeyleri başlangıçta ve entübasyon sonrası 5 . dakikada anlamlı farklılık göstermedi 
Illk olarak 1984'de Wagner ve ark. (3) tarafindan 5 hastaya uygulanan etomidat infüzyonu ile etomidatın kortizol seviyelerini azalttığı ve ratlarda ise $11 \beta$-hidroksilaz inhibisyonu yaptığı gösterilmiştir. Duthie ve ark. (7) genel anestezi altında minör cerrahi geçirecek 12 hastada etomidat ile tiyopentali karşılaştırdıkları çalışmada etomidatın bolus dozunda da $11 \beta$-hidroksilaz inhibisyonu yaptığı gösterilmiştir. Takip eden yıllarda da birçok çalışma etomidatın geçici adrenal supresyon yapıcı etkisini ortaya koymuştur. Annane ve ark. (8) tek doz etomidat verilen hastaların \%94,4ünde verilmeyenlerin ise \%71'inde kortikotropin stimülasyon testine yanıtta bozukluk saptamışlardır. Septik şoku olan yoğun bakım hastalarında yapılan bu çalışmada etomidat kullanılan hastalarda mortalite artışı da gözlenmiştir . Ciddi sepsisli hastalarda yapılan CORTICUS (9) çalışmasından elde edilen veriler de göstermiştir ki 28 günlük mortalite oranları etomidat uygulanan hastalarda daha yüksektir. Meningokokal sepsisli çocuklarda yapılmış retrospektif bir çalışmada ise etomidat uygulanan grupta mortalite \%30 iken uygulanmayan grupta \%12 olarak saptanmış ancak fark istatistiksel olarak anlamlı bulunmamıştır (10).

Öte yandan, etomidatın mortalite üzerindeki bu olumsuz etkilerini desteklemeyen çalışmalar da mevcuttur. Ray ve McKeown (11) tarafından yapılan çalışmada 159 septik şoklu hastada indüksiyonda kullanılan ajanın klinik sonuçları etkilemediği ve etomidat ile mortalitede belirgin artış olmadığı gösterilmiştir. Etomidatın mortaliteye ve klinik sonuçlara etkisi üzerindeki bu şüpheler yoğun bakım hastaları için alternatif bir ilaç arayışını getirmektedir.

Ketaminin hemodinamik yan etkileri ve kullanım kolaylığı bu ajanı stabil olmayan yoğun bakım hastalarının acil entübasyonları sırasında sedasyon için uygun bir aday haline getirmektedir. Son yıllarda yayınlanan KETASED çalışması, kritik hastaların entübasyonu için ketaminin etomidata alternatif olabileceğini savunan tek prospektif çalışmadır (6). Bizim çalışmamız da KETASED çalışması gibi, yoğun bakım hastalarının entübasyonunda tek doz etomidat ile ketamin karşılaştııılı. Ancak KETASED çalışmasından farklı olarak bu çalışmada entübasyon sırasında ve hemen sonrasında ortaya çıkan hemodinamik değişiklikler ve erken metabolik yanıta odaklanıldı.

Hasta sonuçlarının uzun dönemde iyileştirilmesi yoğun bakım alanında gerçekleştirilen çalışmaların en önemli hedefi iken erken dönem ilaç etkilerinin iyi bilinmesi de son derece önemlidir. Acil entübasyon gereksinimi olan yoğun bakım hastaları genellikle birçok sistemde ciddi sorunları olan kritik hastalardan oluşmaktadır. Bu durumda entübasyon sırasında sedasyon amaçlı kullanılan ilaçların uzun dönem hasta sonuçlarına etkisi kadar ilacın verildiği anda neden olduğu hemodinamik değişiklikler ve stres yanıta etkisi de klinisyenlerin ilgisini çekmektedir. Bu çalışmada acil entübasyon gereksinimi olan yoğun bakım hastalarında iki farklı sedatif ajanın uzun dönem etkilerinden çok erken hemodinamik ve metabolik etkilerini incelemeyi hedefledik. Çalışmamıza dahil edilen toplam 22 hastanın demografik özelliklerine baktığımızda ketamin ve etomidat grubu arasında fark yoktu. Hastaların yoğun bakıma kabulleri sırasında önceden var olan sistemik hastalıkların sıklığı açısından gruplar arasında fark yoktu. Yoğun bakıma kabul ediliş nedenlerine baktığımızda etomidat grubunda $\% 83$, ketamin grubunda ise $\% 60$ oranında neden solunum yetmezliği idi.

Entübasyona hemodinamik yanıt açısından ketamin ve etomidat karşılaştıııldığında iki grupta da entübasyonu takiben 60 dakika boyunca kaydedilen sistolik, diyastolik ve ortalama kan basınçları ile kalp hızları benzer bulundu. Ayrıca entübasyon sırasında vazopressör intiyacı ve aritmi gelişimi açısından da iki grup arasında istatistiksel olarak anlamlı fark saptanmadı. Bu sonuçlar, esas olarak daha uzun vadeli hasta sonuçlarını inceleyen, KETASED çalışmasının sonuçları ile uyumluluk göstermektedir. Ketaminin klasik olarak neden olduğu sempatik aktivite artışına bağlı hipertansiyon ve taşikardi yanııının benzodiazepinlerin kullanımı ile azaltılabileceği bilinmektedir (12). Çalışmamızda ketaminin hem halüsinojen etkilerini hem de hemodinamik olarak stabil olmayan, kardiak rezervleri kısıtlı olabilen yoğun bakım hastalarında sorun oluşturabilecek adrenerjik etkilerini azaltmak için ketaminmidazolam kombinasyonu kullandık. Elde ettiğimiz sonuçlar midazolam ile kombine edildiğinde ketaminin istenmeyen sempatik hiperaktivite etkilerinin azaldığını göstermektedir.

Gruplar arasında mortalitede istatistiksel olarak anlamlı fark bulunmadı. Mortalite dışında indüksiyonda kullanılan ajanın klinik sonuçlara, morbiditeye etkilerini de karşısşıırmak amacıyla yoğun bakımda kaldıkları süre içinde hastaların SOFA skorları, yeni gelişen sorunlar ve mekanik ventilatörde kalma süreleri kaydedildi. Hastaların 9 günlük SOFA skorları karşılaştııılı̆̆ında etomidat ve ketamin-midazolam grubunda sonuçlar benzerdi. Ventilatörde ve yoğun bakımda kalma süreleri arasında fark bulunmadı. Istatistiksel olarak anlamlı tek fark yoğun bakımda gelişen sorunlarda bulundu. Etomidat verilen grupta ARDS gelişen hasta sayısı 10 (\%83) iken, ketaminmidazolam grubunda bu sayı $2(\% 20)$ idi $(p=0,008)$. Çalışmamızda hasta sayısının sınırlı olması nedeniyle bu sonuca göre etomidat ile ARDS gelişimini ilişkilendirmek doğru olmayacaktır. Bu konuyla ilgili daha geniş kapsamlı çalışmalar gerekmektedir. 
Stabil olmayan yoğun bakım hastalarında da tercih edilen etomidat yerine ketaminin kullanımı ile ilgili en önemli çekincelerden biri de ketaminin halüsinasyon ve psikozu tetikleme intimalidir. Çalışmamızda başlangıçta ketaminin bu potansiyel yan etkisinin deliryum gelişme sıklığına etkisini araştırmak amacıyla Confusion Assesssment Method for the Intensive Care Unit' in (CAM-ICU) kullanımı planlanmıştı (13). Ancak hastaların APACHE II skorlarından da anlaşılacağı gibi çok ağır bir gruptan oluşmaları ve entübasyon sonrasında ilk 24 saatte CAM-ICU'ya göre değerlendirme yapılamaması nedeniyle bu parametre değerlendirmeye alınamadı.

Entübasyon işlemi için kullanılan sedasyon ajanından beklenen önemli bir özellik de iyi entübasyon koşulları sağlamasıdır. Bu çalışmada ketamin ile etomidatın entübasyon koşullarına etkisi bakımından iki grup arasında sonuçlar benzer bulundu. Laringoskopi derecelendirme skalasına (14) göre yaptığımı değerlendirmede etomidat grubunda sadece 2 (\%17), ketamin-midazolam grubunda ise $1(\% 10)$ hastada kötü sonuç elde ettik. KETASED çalışmasında da entübasyon koşulları açısından ketamin ve etomidat arasında fark bulunmamıştır (6). Hipnotik ilaçların karşılaştııılığı diğer çalışmalarda da entübasyon koşulları benzer bulunmuştur (15). Ancak tüm bu çalışmalarda acil entübasyon için kas gevşetici ajan kullanıımıştır. Çalışmamı kas gevşetici kullanmaksızın etomidat veya ketamin ile iyi entübasyon koşullarının sağlanabileceğini göstermektedir. Çalışmamızda laringoskopi derecelendirme skalasının gruplar arasında benzerlik göstermesinin dışında ek sedatif ilaç ihtiyacının da iki grup arasında farklı olmaması sağlanan entübasyon koşulları açısından ketaminin etomidata alternatif olabileceğini desteklemektedir.

Çalışmamızın başka bir amacı ise entübasyona metabolik yanıtın farkı iki ilacın etkisini araştırmaktı. Bu amaçla stres yanıt belirteçleri olarak kabul gören kan katekolamin düzeyleri (adrenalin ve noradrenalin), kan kortizol ve türevlerinin düzeyleri ve kan glukagon ve insülin gibi farklı ölçümler yapılabilmektedir. Çalışmamıda laboratuardaki ölçüm kolaylıkları ve maliyetlerinin nispeten daha düşük olması nedeniyle entübasyondan hemen önce ve sonraki 5. dakikada alınan arteriyel kan örneklerinde kortizol ve $11 \beta$-deoksikortizol düzeyleri tayin edildi. Özellikle 11ß-deoksikortizol düzeyleri etomidatın neden olduğu adrenal supresyonu saptamada daha spesifik bir ölçüm olabilir. (5) Ancak ölçüm sonuçlarına göre kortizol ve $11 \beta$-deoksikortizol düzeyleri bakımından etomidat ile ketamin grubu arasında istatistiksel olarak anlamlı fark bulunmadı. 11ß-deoksikortizol düzeylerinde her iki grupta da 0 ve 5. dakika arasında artış saptanmadı. Ölçümlerimizin
5. dakika gibi entübasyondan kısa bir süre sonra yapılmış olması bu durumun nedeni olabilir.

Yoğun bakım alanında gerçekleştirilen tek merkezli prospektif çalışmaların çoğunluğunda olduğu gibi bu çalışmanın da önemli kısıtılııkları mevcuttur. Hasta sayısının azlığı bu kısıtlııkların başında yer almaktadır. Ancak daha önce de defalarca atıfta bulunduğumuz çok merkezli KETASED çalışmasında bile her merkezden çalışmaya dahil edilen hasta sayısının tekli rakamlarda kalması dikkat çekicidir. Çalışmanın planlanması aşamasında böyle bir hasta grubuna ait başlangıç ortalama kan basıncı ve standart sapma değerleri elimizde olmadığından güç analizi yapamadık. Ancak çalışmanın verileri ile gerçekleştirdiğimiz post hoc güç analizinde $90 \mathrm{mmHg}$ olan başlangıç ortalama kan basıncının $30 \mathrm{mmHg}$ düşmesi için $(p<0,05$ ve standart sapma $=22 \mathrm{mmHg})$ her grupta 10 hasta olması durumunda çalışmanın gücü \%82 olarak belirlendi. Çalışmanın diğer kısıtlılıkları daha önce de değinildiği gibi strese metabolik yanıın değerlendirilmesi için bakılan parametrelerin sayısı ve sıklığıdır.

Çalışmamızın sonuçları yoğun bakım hastalarının entübasyonunda işlem sırasında ve sonrasında erken dönemde hemodimaik stabilitenin korunması açısından ketaminin etomidata alternatif olabileceği görüşünü desteklemektedir. Benzer şeklide bu çalışmada entübasyona metabolik yanıt ve entübasyon koşulları bakımından da etomidatın yerine ketaminin kullanılabileceği gösterildi.

\section{Kaynaklar}

1. Jackson WL Jr. Should we use etomidate as an induction agent for endotracheal intubation in patients with septic shock?: a critical appraisal. Chest 2005;127:1031-8.

2. Hildreth AN, Mejia VA, Maxwell RA, Smith PW, Dart BW, Barker $D E$. Adrenal suppression following a single dose of etomidate for rapid sequence induction: a prospective randomized study. J Trauma 2008;65:573-9.

3. Wagner RL, White PF, Kan PB, Rosenthal MH, Feldman D. Inhibition of adrenal steroidogenesis by the anesthetic etomidate. N Engl J Med 1984;310:1415-21.

4. Annane D, Sébille V, Charpentier C, Bollaert PE, François B, Korach JM, et al. Effect of treatment with low doses of hydrocortisone and fludrocortisones on mortality in patients with septic shock. JAMA 2002;288:862-71.

5. Vinclair M, Broux C, Faure P, Brun J, Genty C, Jacquot C, et al. Duration of adrenal inhibition following a single dose of etomidate in critically ill patients. Intensive Care Med 2008;34:714-9.

6. Jabre P, Combes X, Lapostolle F, Dhaouadi M, Ricard-Hibon A, Vivien $B$, et al. Etomidate versus ketamine for rapid sequence intubation in acutely ill patients: a multicentre randomised controlled trial. Lancet 2009;374:293-300.

7. Duthie DJ, Fraser R, Nimmo WS. Effect of induction of anaesthesia with etomidate on corticosteroid synthesis in man. Br J Anaesth 1985;57:156-9.

8. Annane D. [Xigris and corticoids: what are the perspectives for the patient with severe sepsis?]. Ann Fr Anesth Reanim 2003;22 Spec No 1: 43-5. 
9. Sprung CL, Annane D, Keh D, Moreno R, Singer M, Freivogel K, et al. Hydrocortisone therapy for patients with septic shock. N Engl J Med 2008;358:111-24.

10. den Brinker M, Hokken-Koelega AC, Hazelzet JA, de Jong FH, Hop WC, Joosten KF. One single dose of etomidate negatively influences adrenocortical performance for at least $24 \mathrm{~h}$ in children with meningococcal sepsis. Intensive Care Med 2008;34:163-8.

11. Ray DC, McKeown DW. Effect of induction agent on vasopressor and steroid use, and outcome in patients with septic shock. Crit Care 2007;11:R56.

12. Tweed WA, Minuck M, Mymin D. Circulatory responses to ketamine anesthesia. Anesthesiology 1972;37:613-9.
13. Ely EW, Margolin R, Francis J, May L, Truman B, Dittus R, et al. Evaluation of delirium in critically ill patients: validation of the Confusion Assessment Method for the Intensive Care Unit (CAM-ICU). Crit Care Med 2001;29:1370-9.

14. Viby-Mogensen J, Engbaek J, Eriksson LI, Gramstad L, Jensen $E$, Jensen FS, et al. Good clinical research practice (GCRP) in pharmacodynamic studies of neuromuscular blocking agents. Acta Anaesthesiol Scand 1996:40:59-74.

15. Sivilotti ML, Ducharme J. Randomized, double-blind study on sedatives and hemodynamics during rapid-sequence intubation in the emergency department: The SHRED Study. Ann Emerg Med 1998;31:313-24. 